\title{
Azodyrecins A-C: Azoxides from a Soil-Derived Streptomyces Species
}

Wibowo, Mario; Gotfredsen, Charlotte H.; Sassetti, Elisa; Melchiorsen, Jette; Clausen, Mads Hartvig; Gram, Lone; Ding, Ling

Published in:

Journal of Natural Products

Link to article, DOI:

10.1021/acs.jnatprod.0c00339

Publication date:

2020

Document Version

Peer reviewed version

Link back to DTU Orbit

Citation (APA):

Wibowo, M., Gotfredsen, C. H., Sassetti, E., Melchiorsen, J., Clausen, M. H., Gram, L., \& Ding, L. (2020). Azodyrecins A-C: Azoxides from a Soil-Derived Streptomyces Species. Journal of Natural Products, 83(12), 3519-3525. https://doi.org/10.1021/acs.jnatprod.0c00339

\section{General rights}

Copyright and moral rights for the publications made accessible in the public portal are retained by the authors and/or other copyright owners and it is a condition of accessing publications that users recognise and abide by the legal requirements associated with these rights.

- Users may download and print one copy of any publication from the public portal for the purpose of private study or research.

- You may not further distribute the material or use it for any profit-making activity or commercial gain

- You may freely distribute the URL identifying the publication in the public portal

If you believe that this document breaches copyright please contact us providing details, and we will remove access to the work immediately and investigate your claim 
Azodyrecins A-C, Azoxides from a Soil-derived Streptomyces sp.

Mario Wibowo, ${ }^{\dagger}$ Charlotte H. Gotfredsen, ${ }^{\ddagger}$ Elisa Sassetti,${ }^{\S}$ Jette Melchiorsen, ${ }^{\dagger}$ Mads Hartvig Clausen,,$^{\S}$ Lone Gram, ${ }^{\dagger}$ Ling Ding ${ }^{\dagger, *}$

${ }^{\dagger}$ Department of Biotechnology and Biomedicine, Technical University of Denmark, Søltofts Plads 221, DK-2800 Kgs. Lyngby, Denmark

tDepartment of Chemistry, Technical University of Denmark, Kemitorvet 207, DK-2800 Kgs. Lyngby, Denmark

${ }^{\S}$ Center for Nanomedicine and Theranostics, Department of Chemistry, Technical University of Denmark, Kemitorvet 207, DK-2800 Kgs. Lyngby, Denmark 


\begin{abstract}
Azoxy compounds belong to a small group of natural products sharing a common functional group with the general structure $\mathrm{RN}=\mathrm{N}^{+}\left(\mathrm{O}^{-}\right) \mathrm{R}$. Three new azoxides, azodyrecins $\mathrm{A}-\mathrm{C}(\mathbf{1}-\mathbf{3})$, were isolated from a soil-derived Streptomyces sp. strain P8-A2. The cis-alkenyl unit in 1-3 was found to readily isomerize to the trans-congeners (4-6). The structures of the new compounds were determined by detailed spectroscopic (1D/2D NMR) and HRMS data analysis. Azodyrecins belong to a new class of natural azoxy compounds and are proposed to derive from L-alanine and alkylamines. The absolute configurations of 1-6 were defined by comparison of ECD spectra. While no antimicrobial effect were observed for $\mathbf{1}$ against Staphylococcus aureus, Vibrio anguillarum, or Candida albicans, azodyrecin A (2) exhibited cytotoxicity against the human leukemia cell line HL-60 with an $\mathrm{IC}_{50}$ value of $2.2 \mu \mathrm{M}$.
\end{abstract}


Natural products containing a nitrogen-nitrogen $(\mathrm{N}-\mathrm{N})$ bond, especially those with an azoxy moiety, are not commonly found in Nature. ${ }^{1}$ Due to their DNA damaging/chelating effects, these azoxy compounds are considered to be hazardous and carcinogenic. ${ }^{2}$ To date, naturally occurring azoxy compounds have been reported from bacteria, fungi, and plants, with examples shown in Figure 1. ${ }^{1,3}$ Some plants, such as, cycads are capable of producing azoxyglycoside cycasin and macrozamin which may play a role as part of the plants' natural defense against herbivores. $^{4}$

Actinobacteria, a notable source of antibiotics, ${ }^{5}$ live in complex biological communities. Interestingly, soil Actinobacteria appear to be producers of the growing number of natural azoxides exemplified by elaiomycins, ${ }^{6}$ maniwamycins, ${ }^{7,8}$ and others. ${ }^{9-13}$ These secondary metabolites exhibit a wide array of biological activity being cytotoxic, or having nematicidal, antifungal, or antibacterial effects. ${ }^{6-10}$ Despite the wide spectrum of bioactivity, limited information is available for the impact of structure variations on the biological effects of naturally occurring azoxy compounds. Moreover, microbial secondary metabolites such as azoxides could play a role as a natural defense against other microbes or animals. Thus, it would be of interest to investigate new azoxy compounds and gain insights into the structural diversity as well as biological activity of this class of compound.

As part of an on-going interest in secondary metabolites from soil microorganisms, several Actinobacteria were isolated from a soil sample collected in the Jægersborg Deer Park, Denmark. From the Streptomyces strain P8-A2, HPLC-HRMS analysis revealed the presence of several previously unknown azoxides. Here we report the isolation and structure elucidation of three new azoxy compounds (1-3) from Streptomyces sp. strain P8-A2, along with evaluation of their antibacterial activity as well as toxicity against brine shrimps and the human cancer cell line HL- 
60. The discovery of these unusual compounds enrich the structural diversity of natural azoxy compounds.

\section{RESULTS AND DISCUSSION}

In the non-polar region, HPLC-HRMS analysis of the crude extract of Streptomyces sp. strain P8-A2 we found several mass peaks of N-N containing compounds indicating the presence of azoxy compounds. To elucidate the lipid-like components, the fermentation was scaled up ( $5 \mathrm{~L}$ solid cultivation), and the EtOAc extract was subjected to silica gel column chromatography, followed by reversed-phase HPLC to obtain unusual azoxy compounds 1-3 (Figure 2).

Compound 1 was isolated as a colorless oil with a molecular formula of $\mathrm{C}_{18} \mathrm{H}_{34} \mathrm{~N}_{2} \mathrm{O}_{3}$, as suggested by (+)-HRESIMS. The characteristic absorption bands at 1467 and $1747 \mathrm{~cm}^{-1}$ in the IR spectrum of $\mathbf{1}$ suggested the presence of an azoxy moiety and a carbonyl group, respectively.,10,14

The ${ }^{1} \mathrm{H}$ NMR data (Table 1) of $\mathbf{1}$ exhibited signals from three methyl groups all appearing as doublets $\left[\delta_{\mathrm{H}} 0.85(6 \mathrm{H})\right.$ and 1.54$]$, a methoxy group $\left(\delta_{\mathrm{H}} 3.72\right)$, and four methine hydrogen atoms corresponding to two $\mathrm{sp}^{3}$ methine groups $\left(\delta_{\mathrm{H}} 1.50\right.$ and 4.55) and two olefinic hydrogen atoms $\left(\delta_{\mathrm{H}}\right.$ 5.78 and 6.82). From the $1 \mathrm{D}{ }^{13} \mathrm{C}$ NMR (Table 1) and 2D edited HSQC spectra, 18 carbon resonances could be identified including three methyl groups, nine methylene groups, four methine groups, and one quaternary carbon atom. The ${ }^{13} \mathrm{C}$ signal at $\delta_{\mathrm{C}} 171.4$ suggested the presence of an ester group in $\mathbf{1}$. The fragment of $\mathrm{H}-2 / \mathrm{H}_{3}-3$ was readily established in the DQF-COSY spectrum. These data, together with $\mathrm{HMBC}$ correlations from $\mathrm{H}-2, \mathrm{H}_{3}-3$ and $\mathrm{H}_{3}-4$ to the ester carbonyl C-1 constructed the partial structure of a methyl propionate moiety (fragment A, Figure 3). Similarly, further analysis of DQF-COSY data and HMBC correlations from the olefinic $\mathrm{H}-2^{\prime}$ to $\mathrm{C}-4$ ', from $\mathrm{H}_{2}-4^{\prime}$ to $\mathrm{C}-6^{\prime}$, from $\mathrm{H}-12^{\prime}$ to $\mathrm{C}-10^{\prime}$, and from both $\mathrm{H}_{3}-13^{\prime}$ and $\mathrm{H}_{3}-14^{\prime}$ to $\mathrm{C}-12^{\prime}$ established a fragment 
of a saturated alkyl chain $\left(\mathrm{C}-1^{\prime}\right.$ along the chain to $\left.\mathrm{C}-12^{\prime}\right)$ with a terminal isopropyl group (fragment B, Figure 3). The ${ }^{1} \mathrm{H}-{ }^{1} \mathrm{H}$ coupling constant $\left(9.0 \mathrm{~Hz}\right.$ ) between $\mathrm{H}-1^{\prime}$ and $\mathrm{H}-2^{\prime}$ indicated a cisconfigured double bond. The two structural moieties were connected by an azoxy linkage, which was implied by the molecular formula and the IR spectrum of $\mathbf{1}$. Furthermore, a weak ${ }^{4} J$-HMBC cross peak was observed from $\mathrm{H}-2$ to $\mathrm{C}-1^{\prime}$, which further confirmed the location of the azoxy group between $\mathrm{C}-2$ and the olefinic carbon $\mathrm{C}-\mathrm{1}^{\prime}$. The oxygen atom of the azoxy moiety was determined to be on the side of the olefin group by the ${ }^{1} \mathrm{H}$ chemical shifts adjacent to the azoxy group,${ }^{15}$ and by comparison of spectroscopic data with related azoxy containing natural products reported in the literature (e.g., elaiomycins, Supporting Information Tables S46 and S47), ${ }^{6}$ maniwamycins,,${ }^{7,8}$ and jietacins. ${ }^{10}$ The characteristic UV absorption maximum at $232 \mathrm{~nm}$, which was also observed in similar alkenyl substituted azoxy compounds (maniwamycins and elaiomycins), ${ }^{6,8}$ determined the Z-configuration of the azoxy group. ${ }^{15}$ In addition, the NOESY spectrum revealed no correlations between $\mathrm{H}-1^{\prime}$ and $\mathrm{H}-2$ or $\mathrm{H}_{3}-3$, which would be likely observed in an E-configuration. ${ }^{14}$ It is worth noting that the azoxy moiety in all previously reported azoxides isolated from Actinobacteria has Z-configuration. ${ }^{1}$ The ECD spectrum of 1 (Figure 4) exhibited a negative Cotton effect at $257 \mathrm{~nm}$ $(\Delta \varepsilon=-3.38)$ and a positive Cotton effect at $227 \mathrm{~nm}(\Delta \varepsilon=+1.48)$, which was similar to those reported for oxidized elaiomycin containing a single stereocenter as in $\mathbf{1} .{ }^{16}$ Notably, oxidized elaiomycin showed a negative Cotton effect at $260 \mathrm{~nm}$ and a positive Cotton effect at $230 \mathrm{~nm} .{ }^{16}$ Despite the existence of a carbonyl group as a another chromophore, the observed Cotton effects derived from a $\pi-\pi^{*}$ excitation from the azoxy moiety, as reported in the extensive ECD studies of LL-BH87 $\alpha$ and elaiomycin. ${ }^{16}$ Therefore, the configuration of $\mathbf{1}$ was defined as $2 S$. On the basis of these data, the structure of $\mathbf{1}$ was established as a new type of azoxide, named azodyrecin A. 
Compound 2 was obtained as a colorless oil and was assigned the molecular formula $\mathrm{C}_{19} \mathrm{H}_{36} \mathrm{~N}_{2} \mathrm{O}_{3}$ following analysis of the (+)-HRESIMS data. The ${ }^{1} \mathrm{H}$ and ${ }^{13} \mathrm{C}$ NMR spectra of 2 were similar to those of $\mathbf{1}$. Comparison of the NMR and MS data between $\mathbf{1}$ and $\mathbf{2}$ revealed that the latter natural product had an additional $-\mathrm{CH}_{2}-$ moiety in the alkyl group. $\mathrm{HMBC}$ correlations from $\mathrm{H}_{3}-$ $14^{\prime}$ to $\mathrm{C}-13^{\prime}$ and C-12' positioned a methyl group at C-13' in $\mathbf{2}$. Similarly, HMBC correlations from $\mathrm{H}_{3}-15^{\prime}$ to $\mathrm{C}-11^{\prime}, \mathrm{C}-12^{\prime}$, and C-13' confirmed the location of a branching methyl group at C-12'. The same $2 S$ configuration previously defined for $\mathbf{1}$ was also assigned for $\mathbf{2}$ following ECD spectra comparison (Figure 4). However, the rotatable nature of the alkyl chain rendered the stereochemical determination at $\mathrm{C}-12^{\prime}$ unfeasible using spectroscopic methods. Thus, the structure of 2 was elucidated and named azodyrecin B (2).

Azodyrecin C (3) was isolated as the third new azoxide, the molecular formula of which was determined as $\mathrm{C}_{20} \mathrm{H}_{38} \mathrm{~N}_{2} \mathrm{O}_{3}$ by (+)-HRESIMS analysis. The NMR and MS data suggested that $\mathbf{3}$ was structurally similar to $\mathbf{1}$, except for the presence of two additional methylene groups in the alkyl substituent in 3 . HMBC correlations from the two overlapped doublet methyl groups at $\delta_{\mathrm{H}}$ 0.86 to $\mathrm{C}-14^{\prime}$ revealed the presence of an isopropyl terminus in $\mathbf{3}$, as also observed in $\mathbf{1}$. The absolute configuration of $\mathbf{3}$ was judged to be identical to $\mathbf{1}$ following chiroptical data comparison (Figure 4). Hence, the structure of $\mathbf{3}$ was established.

Since most natural azoxyalkenes contain a trans-alkenyl moiety, ${ }^{1}$ and it is generally known that compounds bearing a conjugated trans-alkenyl unit are more stable than the cis-isomers, we investigated whether the alkene of $\mathbf{1}-\mathbf{3}$ was prone to isomerize. During the spectroscopic data measurement of compounds $\mathbf{1}-\mathbf{3}$, the alkenyl unit in $\mathbf{1}-\mathbf{3}$ was found to easily isomerize to the transconfiguration as seen in compounds 4-6 (after 30 days of storage in $\mathrm{CDCl}_{3}$, middle panel in Figure 5). Compounds $\mathbf{4}$ and $\mathbf{5}$ were purified from the mixture by RP-HPLC, and their structures were 
elucidated by NMR and MS data analysis (Tables 1 and 2). Compound 6 could not be isolated due to the minute amount. However, the isomerization of compound $\mathbf{3}$ to $\mathbf{6}$ was clearly observed in the ${ }^{1} \mathrm{H}$ NMR spectrum of the mixture of $\mathbf{3}$ and $\mathbf{6}$ (Figure S33, Supporting Information). The presence of a trans-alkene in compounds 4-6 was obvious from the ${ }^{1} \mathrm{H}-{ }^{1} \mathrm{H}$ coupling constant $(13.3 \mathrm{~Hz})$ between $\mathrm{H}-1^{\prime}$ and $\mathrm{H}-2^{\prime}$. This observation provided an additional structural understanding of the natural azoxyalkenes.

The structures of azodyrecins closely resemble elaiomycin and valanimycin, suggesting a similar biosynthetic route. Previously, extensive biosynthesis investigation of both elaiomycin and valanimycin were performed by feeding experiments or/and gene cluster analysis. ${ }^{17-26}$ While Lserine was used as a precursor in both elaiomycin and valanimycin, L-alanine and alkylamine were hypothesized to be the precursors of azodyrecins A-C (1-3). The proposed biosynthetic pathway is shown in Figure 6. In brief, a potential N-hydroxylase could catalyze the formation of a fatty acid-derived amine into a hydroxylamine. Furthermore, L-alanine could be activated by an alanyltRNA synthetase, transferring the alanyl residue from alanyl-tRNA to the hydroxy group of the hydroxylamine to produce an ester intermediate, which was proposed to form azodyrecins following a similar arrangement in valanimycin. ${ }^{23}$ However, formation of the key azoxy moiety in azodyrecins remain elusive despite the recent progress in the biosynthetic characterization of a group of aromatic azoxy compounds, azoxymycins, where the the azoxy bond formation was confirmed to be an enzymatic and non-enzymatic coupled cascade reaction. ${ }^{3,12}$

Potent antimicrobial effects for structurally related azoxy natural products (for example, valanimycin, $\mathrm{MIC}=10 \mu \mathrm{g} / \mathrm{mL}$ against $S$. aureus) were previously reported. ${ }^{9}$ Neither azodyrecin A (1) nor 1'-trans-azodyrecin A (4) had antibacterial activity against Staphylococcus aureus and Vibrio anguillarum. Meanwhile, compound $\mathbf{1}$ was also inactive against Candida albicans. This 
may be due to the chain length of the azoxides. Several studies have reported that azoxides with a shorter alkyl chain, such as azoxybacilin, and valanimycin tend to exhibit higher activity against microbes. ${ }^{27,28,29}$ Meanwhile, natural azoxides with longer aliphatic chains such as elaiomycin derivatives as well as maniwamycin ${ }^{8}$ exhibited weak to no antimicrobial activity. ${ }^{6,30}$ Thus, the main role of azodyrecins may not be as antimicrobials against other microorganisms.

In view of the potential mutation effects of the azoxides and their toxicity to the other higher organisms, such as nematodes and insects, ${ }^{10,28,31,32}$ cytotoxicity of azodyrecin A (1) against brine shrimp Artemia salina was evaluated. At a concentration of $10 \mu \mathrm{g} / \mathrm{mL}$, it caused a $100 \%$ brine shrimp mortality, stronger than the positive control elaiophylin $(10 \mu \mathrm{g} / \mathrm{mL}, 78 \%)$. Further attempts to test compound $\mathbf{1}$ for in vitro cytotoxicity against cell lines were unsuccessful due to the rapid decomposition of $\mathbf{1}$ during handling and biological testing. Therefore, we tested the in vitro cytotoxic effect of the most abundant compound, azodyrecin B (2), against the human leukemia cell line HL-60 using the AlamarBlue assay. Compound 2 did exhibit cytotoxicity against the HL-60 cell line, with an $\mathrm{IC}_{50}$ value of $2.2 \mu \mathrm{M}$ (Supporting Information Figure S48).

\section{EXPERIMENTAL SECTION}

General Experimental Procedures. Specific rotations were acquired using a PerkinElmer 241 polarimeter. ECD spectra were obtained on a JASCO J-1500 CD Spectrometer and processed using the software SDAR. ${ }^{33}$ IR data were acquired on Bruker Alpha FTIR spectrometer using OPUS version 7.2. NMR spectra were acquired on $800 \mathrm{MHz}$ Bruker Avance III spectrometer equipped with a TCI CryoProbe using standard pulse sequences. The ${ }^{1} \mathrm{H}$ and ${ }^{13} \mathrm{C}$ NMR chemical shifts were referenced to the residual solvent peaks at $\delta_{\mathrm{H}} 7.26$ and $\delta_{\mathrm{C}} 77.16 \mathrm{ppm}$ for $\mathrm{CDCl}_{3}$, and $\delta_{\mathrm{H}} 2.50$ and $\delta_{\mathrm{C}} 39.5 \mathrm{ppm}$ for DMSO- $d 6$. NMR data were processed using MestReNova 11.0. 
UHPLC-HRMS was performed on an Agilent Infinity 1290 UHPLC system equipped with a diode array detector. UV-Vis spectra were recorded from 190 to $640 \mathrm{~nm}$. Biotage Isolera One Flash Chromatography system and Biotage SNAP KP-Sil (50 $\mu \mathrm{m}, 50 \mathrm{~g})$ Si gel cartridge were used for flash chromatography. All solvents and chemicals used for HRMS and chromatography were VWR Chemicals LC-MS grade, while for metabolites extraction, the solvents were of HPLC grade (VWR Chemicals).

Strain Isolation and Taxonomic Classification. The bacterial strain was isolated from soil collected in September 2018 in the UNESCO World Heritage Site, Jægersborg Deer Park (Dyrehaven in Danish), Denmark. The soil samples (1.0 g) were diluted in sterile water to prepare a $10^{-3} \mathrm{~g} / \mathrm{mL}$ suspension. The suspension $(300 \mu \mathrm{L})$ was inoculated onto humic acid-vitamin (HV) agar and incubated at $28{ }^{\circ} \mathrm{C}$ for 14 days. HV agar was prepared as previously described. ${ }^{34}$ Purification of the bacterial strains was performed by re-plating different colonies on coconut mannitol (CM) agar plates containing $20 \mathrm{~g} \mathrm{~L}^{-1}$ coconut powder (Green Organic), $20 \mathrm{~g} \mathrm{~L}^{-1}$ mannitol (Sigma Aldrich), and $20 \mathrm{~g} \mathrm{~L}^{-1}$ agar (Difco); until an axenic culture was obtained. The identification of Streptomyces sp. strain P8-A2 was performed using 16S rRNA gene sequence analysis and comparison with NCBI data, which showed 100\% similarity to Streptomyces mirabilis strain 3662. The nucleotide sequence was deposited in GenBank (www.ncbi.nlm.nih.gov) under the accession number MN826478.

Bacterial cultivation. Spores of strain P8-A2 were inoculated into $500 \mathrm{~mL}$ conical flask containing $150 \mathrm{~mL}$ of liquid $\mathrm{CM}$ medium and incubated at $28^{\circ} \mathrm{C}$ for 2 days at $180 \mathrm{rpm}$ to afford a seed culture. A volume of $100 \mu \mathrm{L}$ of the seed culture was inoculated on CM agar plates and incubated in the dark at $28{ }^{\circ} \mathrm{C}$ for 7 days. A total of 200 plates of $\mathrm{CM}$ agar (5 L in total) were prepared. 
Extraction and Isolation. The cultured agar was extracted with EtOAc $(2 \times 2.5 \mathrm{~L})$ under ultrasonication for $30 \mathrm{~min}$. The EtOAc phase was filtered and removed under reduced pressure to obtain 2.4 gram of extract. The extract was chromatographed over a Si-gel flash cartridge eluted with a stepwise $n$-heptane/EtOAc solvent system (100\% $n$-heptane to $100 \%$ EtOAc) at a flow rate of $50 \mathrm{~mL} / \mathrm{min}$ to give 22 fractions (132 mL each). Similar fractions were pooled following (+)HRESIMS analysis to afford 12 fractions (A1-A12). Fraction A4 (775.2 mg) was further fractionated using a semi-preparative phenyl-hexyl HPLC column $(250$ x $10 \mathrm{~mm}$, LunaPhenomemex $5 \mu \mathrm{m} 100 \AA$ ). A linear gradient from $67 \% \mathrm{CH}_{3} \mathrm{CN}-\mathrm{H}_{2} \mathrm{O}$ (50 ppm TFA) to $80 \%$ $\mathrm{CH}_{3} \mathrm{CN}-\mathrm{H}_{2} \mathrm{O}$ (50 ppm TFA) at a flowrate of $4 \mathrm{~mL} / \mathrm{min}$ was run over 60 min to yield compounds 1 (9.5 mg, $\left.t_{\mathrm{R}} 30-31 \mathrm{~min}\right), 2\left(22.3 \mathrm{mg}, t_{\mathrm{R}} 36-37 \mathrm{~min}\right)$, and 3 (2.3 min, $\left.t_{\mathrm{R}} 42-43 \mathrm{~min}\right)$. The mixture (9.5 mg) of compounds $\mathbf{1}$ and $\mathbf{4}$ was separated using a semi-preparative phenyl-hexyl HPLC column $(250 \times 10$ mm, Gemini-Phenomemex $5 \mu \mathrm{m} 100 \AA$ A ) with a linear gradient from $75 \%$ $\mathrm{CH}_{3} \mathrm{CN}-\mathrm{H}_{2} \mathrm{O}$ (50 ppm TFA) to $83 \% \mathrm{CH}_{3} \mathrm{CN}-\mathrm{H}_{2} \mathrm{O}$ (50 ppm TFA) over 20 min to afford compound $4(0.8 \mathrm{mg})$. The mixture $(22.3 \mathrm{mg})$ of $\mathbf{2}$ and $\mathbf{5}$ was further separated using a semi-preparative phenyl-hexyl HPLC column ( 250 x 10 mm, Gemini-Phenomemex $5 \mu$ m $100 \AA$ Å). A gradient from $78 \% \mathrm{CH}_{3} \mathrm{CN}-\mathrm{H}_{2} \mathrm{O}$ (50 ppm TFA) to $85 \% \mathrm{CH}_{3} \mathrm{CN}-\mathrm{H}_{2} \mathrm{O}$ (50 ppm TFA) over 20 min was used to afford compound 5 ( $2.5 \mathrm{mg})$.

Antimicrobial activity test. The antimicrobial activity of pure $\mathbf{1}$ and $\mathbf{4}$ were assessed against the Gram-negative fish pathogen $V$. anguillarum strain $90-11-287^{35}$ and the Gram-positive human pathogen S. aureus strain $8325^{36}$ in a well diffusion agar assay. The pathogens were seeded in Instant Ocean (IO) agar plates containing 3\% Instant Ocean (Aquarium Systems Inc.), $3.33 \mathrm{~g}$ $\mathrm{L}^{-1}$ Casamino acids, $4 \mathrm{~g} \mathrm{~L}^{-1}$ glucose, and $10 \mathrm{~g} \mathrm{~L}^{-1}$ agar. ${ }^{37} \mathrm{~A}$ volume of $30 \mu \mathrm{L}$ of compounds 1 and 4 solutions in $\mathrm{MeOH}(100 \mu \mathrm{g} / 100 \mu \mathrm{L})$ were added to wells (diameter $=4 \mathrm{~mm}$; distance between 
the wells $=32-38 \mathrm{~mm}$ ) punched into the agar plate alongside medium and $\mathrm{MeOH}$ control. Sterile filtered supernatant from 3 day Marine Broth (Difco 2216) cultures of a Phaeobacter inhibens DSM17395 producing tropodithietic acid was used as positive control. Following $24 \mathrm{~h}$ incubation at $25^{\circ} \mathrm{C}$, the diameters of the resulting inhibition zones were measured.

Compound 1 was also evaluated for its antifungal effect against Candida albicans IBT $654 .^{38}$ The test plates for C. albicans were prepared by pouring $14 \mathrm{ml}$ of media (40 $\mathrm{g}$ glucose, 10 g Bacto-Pepton, 1 L Tap water, $\mathrm{pH} 4.8,36 \mathrm{~g}$ agar) as a base layer; after solidifying, this was inoculated with the fungus. Paper disks with a diameter of $6 \mathrm{~mm}$ were impregnated with $80 \mu \mathrm{g}$ of pure compound 1 (dissolved in $\mathrm{CH}_{2} \mathrm{Cl}_{2}$ ); the disks were dried under sterile conditions and placed on the surface of test plates. The test plate was incubated at $28{ }^{\circ} \mathrm{C}$ for $16-24 \mathrm{~h}$. After incubation, the diameter of inhibition zones was measured.

Brine shrimp toxicity assay. Toxicity assay was carried out using brine shrimp mortality test according to the Meyer method with slight modifications. ${ }^{39}$ The eggs of Artemia salina were hatched in a beaker filled with artificial seawater. Seawater $(4.95 \mathrm{~mL})$ containing 30-40 nauplii was added to each glass test tube. A volume of $50 \mu \mathrm{L}$ solution of azodyrecin A (1) in dimethylsulfoxide (DMSO) was added to the test tube with a final concentration of $10 \mu \mathrm{g} / \mathrm{mL}$. Elaiophylin was used as a positive control. DMSO $(50 \mu \mathrm{L})$ was used as a negative control. After incubation for $24 \mathrm{~h}$, the mortality of brine shrimps was calculated.

Cytotoxicity assay. Cytotoxicity against the human cell line HL-60 was evaluated at 48 hours for azodyrecin B (2), using AlamarBlue (Thermos Scientific, Kansas, USA). The assay was performed in 96 well plates (Costar 3595, Corning, New York, USA), with an assay volume of $200 \mu \mathrm{L}$. HL-60 cells were cultured at $37^{\circ} \mathrm{C}$ in a $5 \% \mathrm{CO}_{2}$ incubator and seeded in the plate with a cell density of $2 \times 10^{5}$ cells $/ \mathrm{mL}$. The cells were treated with $200 \mathrm{~nL}$ azodyrecin B (2) (dissolved in 
DMSO) using an Echo 550 liquid handler (Labcyte, California, USA) to dispense. After 48 hours of incubation in a $5 \% \mathrm{CO}_{2}$ incubator at $37{ }^{\circ} \mathrm{C}, 20 \mu \mathrm{L}$ of AlamarBlue were added to each well and the cells were further incubated under the same conditions for 5 hours. Fluorescence (excitation: $544 \mathrm{~nm}$, emission: $590 \mathrm{~nm}$ ) was detected by an Infinite M200 plate reader (Tecan, Switzerland). The dose-response of the compound was tested in 10 concentrations, with a starting concentration of $10 \mu \mathrm{M}$ and 1:2 dilutions in DMSO. Control wells were treated with DMSO only and used as the maximal cellular growth reference, while wells containing only media were used to perform the background signal correction. The software Prism 5.03 was used for data analysis (GraphPad Software, USA).

Azodyrecin A (1): colorless oil; $[\alpha]_{D}^{20}-66.7\left(\mathrm{c} 0.39, \mathrm{CH}_{3} \mathrm{OH}\right), \mathrm{UV}\left(\mathrm{CH}_{3} \mathrm{CN} / \mathrm{H}_{2} \mathrm{O}\right) \lambda_{\max }(\%)$ $232(100 \%) \mathrm{nm} ; \mathrm{ECD} \lambda_{\text {ext }}(\Delta \varepsilon)\left(\mathrm{CH}_{3} \mathrm{OH}\right) 227(+1.48), 257(-3.38) \mathrm{nm}$; IR (ATR) $v_{\max } 2952,2925$, $2854,1747,1557,1468,1434,1378,1320,1198,1171 \mathrm{~cm}^{-1} ;{ }^{1} \mathrm{H}$ NMR see Table $1 ;{ }^{13} \mathrm{C}$ NMR see Table 1; (+)-HRESIMS m/z $349.2471[\mathrm{M}+\mathrm{Na}]^{+}\left(\right.$calcd for $\left.\mathrm{C}_{18} \mathrm{H}_{34} \mathrm{~N}_{2} \mathrm{O}_{3} \mathrm{Na}, 349.2462\right)$.

Azodyrecin B (2): colorless oil; $[\alpha]_{D}^{20}-64.6\left(\mathrm{c} 0.46, \mathrm{CH}_{3} \mathrm{OH}\right), \mathrm{UV}\left(\mathrm{CH}_{3} \mathrm{CN} / \mathrm{H}_{2} \mathrm{O}\right) \lambda_{\max }(\%)$ $235(100 \%) \mathrm{nm} ; \mathrm{ECD} \lambda_{\text {ext }}(\Delta \varepsilon)\left(\mathrm{CH}_{3} \mathrm{OH}\right) 227(+1.69), 257(-3.63) \mathrm{nm}$; IR (ATR) $v_{\max } 2925,2854$, 1747, 1556, $1434 \mathrm{~cm}^{-1} ;{ }^{1} \mathrm{H}$ NMR see Table $1 ;{ }^{13} \mathrm{C}$ NMR see Table 1; (+)-HRESIMS $\mathrm{m} / z 363.2621$ $[\mathrm{M}+\mathrm{Na}]^{+}$(calcd for $\mathrm{C}_{19} \mathrm{H}_{36} \mathrm{~N}_{2} \mathrm{O}_{3} \mathrm{Na}, 363.2618$ ).

Azodyrecin C (3): colorless oil; $[\alpha]_{D}^{20}-52.2\left(\mathrm{c} 0.23, \mathrm{CH}_{3} \mathrm{OH}\right), \mathrm{UV}\left(\mathrm{CH}_{3} \mathrm{CN} / \mathrm{H}_{2} \mathrm{O}\right) \lambda_{\max }(\%)$ $235(100 \%) \mathrm{nm}$; ECD $\lambda_{\text {ext }}(\Delta \varepsilon)\left(\mathrm{CH}_{3} \mathrm{OH}\right) 226(+1.89), 257(-4.20) \mathrm{nm}$; IR (ATR) $v_{\max } 2925,2854$, 1748, 1557, 1468, 1436, 1320, 1198, 1172, $1132 \mathrm{~cm}^{-1} ;{ }^{1} \mathrm{H}$ NMR see Table $1 ;{ }^{13} \mathrm{C}$ NMR see Table 1; (+)-HRESIMS m/z $377.2783[\mathrm{M}+\mathrm{Na}]^{+}\left(\right.$calcd for $\mathrm{C}_{20} \mathrm{H}_{38} \mathrm{~N}_{2} \mathrm{O}_{3} \mathrm{Na} 377.2775$ ).

I'-trans-Azodyrecin A (4): colorless oil; $[\alpha]_{D}^{20}-6.3\left(\mathrm{c} 0.08, \mathrm{CH}_{3} \mathrm{OH}\right), \mathrm{UV}\left(\mathrm{CH}_{3} \mathrm{CN} / \mathrm{H}_{2} \mathrm{O}\right)$ $\lambda_{\max }(\%) 236(100 \%) \mathrm{nm} ; \mathrm{ECD} \lambda_{\mathrm{ext}}(\Delta \varepsilon)\left(\mathrm{CH}_{3} \mathrm{OH}\right) 229(+0.80), 257(-0.82) \mathrm{nm}$; IR (ATR) $v_{\max }$ 
2926, 2854, 1747, 1557, 1468, 1433, 1321, 1171, $1128 \mathrm{~cm}^{-1} ;{ }^{1} \mathrm{H}$ NMR see Table $1 ;{ }^{13} \mathrm{C}$ NMR see

Table 1; (+)-HRESIMS m/z 349.2467 [M+Na] ${ }^{+}$(calcd for $\mathrm{C}_{18} \mathrm{H}_{34} \mathrm{~N}_{2} \mathrm{O}_{3} \mathrm{Na}, 349.2462$ ).

I'-trans-Azodyrecin B (5): colorless oil; $[\alpha]_{D}^{20}+5.0\left(\mathrm{c} 0.26, \mathrm{CH}_{3} \mathrm{OH}\right), \mathrm{UV}\left(\mathrm{CH}_{3} \mathrm{CN} / \mathrm{H}_{2} \mathrm{O}\right)$

$\lambda_{\max }(\%) 237(100 \%)$ nm; ECD $\lambda_{\text {ext }}(\Delta \varepsilon)\left(\mathrm{CH}_{3} \mathrm{OH}\right) 256(-0.03) \mathrm{nm}$; IR (ATR) $v_{\max } 2925,2854$,

1748, 1558, 1434, $1322 \mathrm{~cm}^{-1} ;{ }^{1} \mathrm{H}$ NMR see Table $1 ;{ }^{13} \mathrm{C}$ NMR see Table $1 ;(+)$-HRESIMS $\mathrm{m} / \mathrm{z}$

$341.2805[\mathrm{M}+\mathrm{H}]^{+}$(calcd for $\mathrm{C}_{19} \mathrm{H}_{37} \mathrm{~N}_{2} \mathrm{O}_{3}, 341.2799$ ).

\section{ASSOCIATED CONTENT}

\section{Supporting Information}

NMR spectra of compounds 1-5 and ECD curves for compounds 4-6. This material is available free of charge via the Internet at http://pubs.acs.org.

\section{AUTHOR INFORMATION}

\section{Corresponding Author}

* Tel: (+) 45-50333791, E-mail: lidi@dtu.dk.

Notes

The authors declare no competing financial interest.

\section{ACKNOWLEDGMENTS}

This study was supported by the Danish National Research Foundation (DNRF137) as part of the Center for Microbial Secondary Metabolites (CeMiSt). The NMR Center • DTU and the Villum Foundation are acknowledged for access to the $800 \mathrm{MHz}$ spectrometer. M.H.C. acknowledges funding for the DTU Screening Core from the Novo Nordisk Foundation (grant no. 
NNF19OC0055818) and the Carlsberg Foundation (grant no. CF19-0072). E.S. was supported by the European Union's Horizon 2020 research and innovation program under the Marie Skłodowska-Curie actions (grant agreement No 754462) and by DTU.

\section{REFERENCES}

(1) Blair, L. M.; Sperry, J. J. Nat. Prod. 2013, 76, 794-812.

(2) Schoental, R. Nature 1969, 221, 765-766.

(3) Guo, Y. Y.; Li, Z. H.; Xia, T. Y.; Du, Y. L.; Mao, X. M.; Li, Y. Q. Nat. Commun. 2019, 10, 4420.

(4) Reams, R. Y.; Janovitz, E. B.; Robinson, F. R.; Sullivan, J. M.; Casanova, C. R.; Más, E. J. Vet. Diagnostic Investig. 1993, 5, 488-494.

(5) Takahashi, Y.; Nakashima, T. Antibiotics 2018, 7, 45.

(6) Ding, L.; Ndejouong, B. L. S. T.; Maier, A.; Fiebig, H.-H.; Hertweck, C. J. Nat. Prod. 2012, 75, $1729-1734$.

(7) Takahashi, Y.; Nakayama, M.; Watanabe, I.; Deushi, T.; Ishiwata, H.; Shiratsuchi, M.; Otani, G. J. Antibiot. 1989, 42, 1541-1546.

(8) Fukumoto, A.; Murakami, C.; Anzai, Y.; Kato, F. J. Antibiot. 2016, 69, 395-399.

(9) Yamato, M.; Iinuma, H.; Naganawa, H.; Yamagishi, Y.; Hamada, M.; Masuda, T.; Umezawa, H.; Abe, V.; Hori, M. J. Antibiot. 1986, 39, 184-191.

(10) Sugawara, A.; Kubo, M.; Nakashima, T.; Hirose, T.; Tsunoda, N.; Yahagi, K.; Asami, Y.; Yamada, T.; Shiomi, K.; Takahashi, Y.; et al. Tetrahedron 2015, 71, 2149-2157.

(11) Watanabe, M.; Sugawara, A.; Noguchi, Y.; Hirose, T.; Ōmura, S.; Sunazuka, T.; Horie, R. Eur. J. Med. Chem. 2019, 178, 636-647.

(12) Guo, Y. Y.; Li, H.; Zhou, Z. X.; Mao, X. M.; Tang, Y.; Chen, X.; Jiang, X.-H.; Liu, Y.; Jiang, H.; Li, Y. Q. Org. Lett. 2015, 17, 6114-6117.

(13) Kim, B.-Y.; Willbold, S.; Kulik, A.; Helaly, S. E.; Zinecker, H.; Wiese, J.; Imhoff, J. F.; Goodfellow, M.; Süssmuth, R. D.; Fiedler, H.-P. J. Antibiot. 2011, 64, 595-597.

(14) Helaly, S. E.; Pesic, A.; Fiedler, H.-P.; Süssmuth, R. D. Org. Lett. 2011, 13, 1052-1055.

(15) Taylor, K. G.; Riehl, T. J. Am. Chem. Soc. 1972, 94, 250-255.

(16) McGahren, W. J.; Kunstmann, M. P. J. Am. Chem. Soc. 1970, 92, 1587-1590.

(17) Parry, R. J.; Li, W. J. Biol. Chem. 1997, 272, 23303-23311.

(18) Parry, R. J.; Li, Y.; Lii, F. L. J. Am. Chem. Soc. 1992, 114, 10062-10064.

(19) Garg, R. P.; Yunqing, M.; Hoyt, J. C.; Parry, R. J. Mol. Microbiol. 2002, 46, 505-517. 
(20) Parry, R. J.; Li, W. Arch. Biochem. Biophys. 1997, 339, 47-54.

(21) Parry, R. J.; Li, W.; Cooper, H. N. J. Bacteriol. 1997, 179, 409-416.

(22) Jahn, D.; Verkamp, E.; Söll, D. Trends Biochem. Sci. 1992, 17, 215-218.

(23) Garg, R. P.; Qian, X. L.; Alemany, L. B.; Moran, S.; Parry, R. J. Proc. Natl. Acad. Sci. 2008, 105, 6543-6547.

(24) Tao, T.; Alemany, L. B.; Parry, R. J. Org. Lett. 2003, 5, 1213-1215.

(25) Parry, R. J.; Rao, H. S. P.; Mueller, J. J. Am. Chem. Soc. 1982, 104, 339-340.

(26) Parry, R. J.; Mueller, J. V. J. Am. Chem. Soc. 1984, 106, 5764-5765.

(27) Fujiu, M.; Sawairi, S.; Shimada, H.; Takaya, H.; Aoki, Y.; Okuda, T.; Yokose, K. J. Antibiot. 1994, 47, 833-835.

(28) Otoguro, K.; Imamura, N.; Kuga, H.; Takahashi, Y.; Masuma, R.; Tanaka, Y.; Tanaka, H.; En-tai, Y. J. Antibiot. 1987, 40, 623-629.

(29) Yamato, M.; Umezawa, H.; Sakata, N.; Moriya, Y.; Hori, M. J. Antibiot. 1987, 40, 558-560.

(30) Manderscheid, N.; Helaly, S. E.; Kulik, A.; Wiese, J.; Imhoff, J. F.; Fiedler, H. P.; Süssmuth, R. D. J. Antibiot. 2013, 66, 85-88.

(31) Sugawara, A.; Kubo, M.; Hirose, T.; Yahagi, K.; Tsunoda, N.; Noguchi, Y.; Nakashima, T.; Takahashi, Y.; Welz, C.; Mueller, D.; et al. Eur. J. Med. Chem. 2018, 145, 524-538.

(32) Claydon, N.; Grove, J. F. J. Chem. Soc. Perkin Trans. 1 1978, No. 2, 171-173.

(33) Weeratunga, S.; Hu, N.-J.; Simon, A.; Hofmann, A. BMC Bioinformatics 2012, 13, 201.

(34) Hayakawa, M.; Nonomura, H. J. Ferment. Technol. 1987, 65, 501-509.

(35) Skov, M. N.; Pedersen, K.; Larsen, J. L. Appl. Environ. Microbiol. 1995, 61, 1540-1545.

(36) Novick, R. Virology 1967, 33, 155-166.

(37) Hjelm, M.; Bergh, Ø.; Riaza, A.; Nielsen, J.; Melchiorsen, J.; Jensen, S.; Duncan, H.; Ahrens, P.; Birkbeck, H.; Gram, L. Syst. Appl. Microbiol. 2004, 27, 360-371.

(38) Petersen, L. M.; Holm, D. K.; Knudsen, P. B.; Nielsen, K. F.; Gotfredsen, C. H.; Mortensen, U. H.; Larsen, T. O. J. Antibiot. 2015, 68, 201-205.

(39) Meyer, B. N.; Ferrigni, N. R.; Putnam, J. E.; Jacobsen, L. B.; Nichols, D. E.; McLaughlin, J. L. Planta Med. 1982, 45, 31-34. 
Table 1. ${ }^{1} \mathrm{H}(800 \mathrm{MHz})$ and ${ }^{13} \mathrm{C}(200 \mathrm{MHz}) \mathrm{NMR}$ data for $\mathbf{1}-\mathbf{5}\left(\mathbf{1}-\mathbf{3}\right.$ in $\mathrm{CDCl}_{3} ; \mathbf{4}-\mathbf{5}$ in DMSO-d6)

\begin{tabular}{|c|c|c|c|c|c|c|c|c|c|c|}
\hline \multirow[b]{2}{*}{ pos. } & \multicolumn{2}{|r|}{1} & \multicolumn{2}{|r|}{2} & \multicolumn{2}{|r|}{3} & \multicolumn{2}{|r|}{4} & \multicolumn{2}{|r|}{5} \\
\hline & $\delta_{\mathrm{C}}$, type & $\delta_{\mathrm{H},}(J$ in $\mathrm{Hz})$ & $\delta_{\mathrm{C}}$, type & $\delta_{\mathrm{H}}(J$ in $\mathrm{Hz})$ & $\delta_{\mathrm{C}}$, type & $\delta_{\mathrm{H}}(J$ in $\mathrm{Hz})$ & $\delta_{\mathrm{C}}$, type & $\delta_{\mathrm{H}}(J$ in $\mathrm{Hz})$ & $\delta_{\mathrm{C}}$, type & $\delta_{\mathrm{H}}(J$ in $\mathrm{Hz})$ \\
\hline 1 & $171.4, \mathrm{C}$ & - & $171.4, \mathrm{C}$ & - & $171.4, \mathrm{C}$ & - & $170.5, \mathrm{C}$ & - & $170.5, \mathrm{C}$ & - \\
\hline 2 & $\begin{array}{l}58.8, \\
\mathrm{CH}\end{array}$ & $4.55, \mathrm{q}(7.2)$ & $\begin{array}{l}58.8, \\
\mathrm{CH}\end{array}$ & $4.55, \mathrm{q}(7.2)$ & $58.8, \mathrm{CH}$ & $4.56, \mathrm{q}(7.2)$ & $58.4, \mathrm{CH}$ & $4.47, \mathrm{q}(7.2)$ & $\begin{array}{l}58.4, \\
\mathrm{CH}\end{array}$ & $4.47, \mathrm{q}(7.2)$ \\
\hline 3 & $\begin{array}{l}15.8, \\
\mathrm{CH}_{3}\end{array}$ & $1.54, \mathrm{~d}(7.2)$ & $\begin{array}{l}15.8, \\
\mathrm{CH}_{3}\end{array}$ & $1.54, \mathrm{~d}(7.2)$ & $15.8, \mathrm{CH}_{3}$ & $1.55, \mathrm{~d}(7.2)$ & $15.6, \mathrm{CH}_{3}$ & $1.43, \mathrm{~d}(7.2)$ & $\begin{array}{l}15.6, \\
\mathrm{CH}_{3}\end{array}$ & $1.43, \mathrm{~d}(7.2)$ \\
\hline 4 & $\begin{array}{l}52.3, \\
\mathrm{CH}_{3}\end{array}$ & $3.72, \mathrm{~s}$ & $\begin{array}{l}52.3, \\
\mathrm{CH}_{3}\end{array}$ & $3.73, \mathrm{~s}$ & $52.4, \mathrm{CH}_{3}$ & $3.73, \mathrm{~s}$ & $51.9, \mathrm{CH}_{3}$ & $3.61, \mathrm{~s}$ & $\begin{array}{l}51.9 \\
\mathrm{CH}_{3}\end{array}$ & $3.61, \mathrm{~s}$ \\
\hline $1^{\prime}$ & $\begin{array}{l}\text { 135.1, } \\
\mathrm{CH}\end{array}$ & $\begin{array}{l}6.82, \mathrm{dt} \\
(9.0,1.8)\end{array}$ & $\begin{array}{l}135.2, \\
\mathrm{CH}\end{array}$ & $\begin{array}{l}6.82, \mathrm{dt} \\
(9.1,1.7)\end{array}$ & $\begin{array}{l}135.2, \\
\mathrm{CH}\end{array}$ & $\begin{array}{l}6.72, \mathrm{dt} \\
(9.0,1.8)\end{array}$ & $\begin{array}{l}137.0, \\
\mathrm{CH}\end{array}$ & $\begin{array}{l}7.29, \mathrm{dt} \\
(13.3,1.5)\end{array}$ & $\begin{array}{l}137.0, \\
\mathrm{CH}\end{array}$ & $\begin{array}{l}7.23, \mathrm{dt} \\
(13.3,1.5)\end{array}$ \\
\hline $2^{\prime}$ & $\begin{array}{l}135.6, \\
\mathrm{CH}\end{array}$ & $\begin{array}{l}5.78, \mathrm{dt} \\
(9.0,7.5)\end{array}$ & $\begin{array}{l}135.6, \\
\mathrm{CH}\end{array}$ & $\begin{array}{l}5.78, \mathrm{dt} \\
(9.1,7.5)\end{array}$ & $\begin{array}{l}135.7, \\
\mathrm{CH}\end{array}$ & $\begin{array}{l}5.78, \mathrm{dt} \\
(9.0,7.5)\end{array}$ & $\begin{array}{l}135.7, \\
\mathrm{CH}\end{array}$ & $\begin{array}{l}6.91, \mathrm{dt} \\
(13.3,7.5)\end{array}$ & $\begin{array}{l}135.7, \\
\mathrm{CH}\end{array}$ & $\begin{array}{l}6.91, \mathrm{dt} \\
(13.3,7.5)\end{array}$ \\
\hline $3^{\prime}$ & $\begin{array}{l}27.3 \text {, } \\
\mathrm{CH}_{2}\end{array}$ & $2.64, \mathrm{~m}$ & $\begin{array}{l}27.3 \text {, } \\
\mathrm{CH}_{2}\end{array}$ & $2.64, \mathrm{~m}$ & 27.3, $\mathrm{CH}_{2}$ & $2.64, \mathrm{~m}$ & $\begin{array}{l}27.64^{*}, \\
\mathrm{CH}_{2}\end{array}$ & $2.21, \mathrm{~m}$ & $\begin{array}{l}27.6 \text {, } \\
\mathrm{CH}_{2}\end{array}$ & $2.21, \mathrm{~m}$ \\
\hline $4^{\prime}$ & $\begin{array}{l}29.1 \\
\mathrm{CH}_{2}\end{array}$ & $1.45, \mathrm{~m}$ & $\begin{array}{l}29.1 \\
\mathrm{CH}_{2}\end{array}$ & $1.45, \mathrm{~m}$ & $29.1, \mathrm{CH}_{2}$ & $1.45, \mathrm{~m}$ & $\begin{array}{l}27.60^{*}, \\
\mathrm{CH}_{2}\end{array}$ & $1.43, \mathrm{~m}$ & $\begin{array}{l}27.7 \\
\mathrm{CH}_{2}\end{array}$ & $1.43, \mathrm{~m}$ \\
\hline $5^{\prime}$ & $\begin{array}{l}29.4, \\
\mathrm{CH}_{2}\end{array}$ & $1.31, \mathrm{~m}$ & $\begin{array}{l}29.4, \\
\mathrm{CH}_{2}\end{array}$ & $1.32, \mathrm{~m}$ & $29.4, \mathrm{CH}_{2}$ & $1.32, \mathrm{~m}$ & $28.5, \mathrm{CH}_{2}$ & $1.21-1.29, \mathrm{~m}$ & $\begin{array}{l}28.7, \\
\mathrm{CH}_{2}\end{array}$ & $1.18-1.32, \mathrm{~m}$ \\
\hline $6^{\prime}$ & $\begin{array}{l}27.3 \text {, } \\
\mathrm{CH}_{2}\end{array}$ & $\begin{array}{l}1.22-1.29 \\
\mathrm{~m}\end{array}$ & $\begin{array}{l}27.2, \\
\mathrm{CH}_{2}\end{array}$ & $\begin{array}{l}1.20-1.30 \\
\mathrm{~m}\end{array}$ & 27.3, $\mathrm{CH}_{2}$ & $\begin{array}{l}1.22-1.29, \\
\mathrm{~m}\end{array}$ & 28.7, $\mathrm{CH}_{2}$ & $1.21-1.29, \mathrm{~m}$ & $\begin{array}{l}28.6 \text {, } \\
\mathrm{CH}_{2}\end{array}$ & $1.18-1.32, \mathrm{~m}$ \\
\hline $7^{\prime}$ & $\begin{array}{l}29.5 \\
\mathrm{CH}_{2}\end{array}$ & $\begin{array}{l}1.22-1.29 \\
\mathrm{~m}\end{array}$ & $\begin{array}{l}29.5^{*} \\
\mathrm{CH}_{2}\end{array}$ & $\begin{array}{l}1.20-1.30 \\
\mathrm{~m}\end{array}$ & $29.5, \mathrm{CH}_{2}$ & $\begin{array}{l}1.22-1.29 \\
\mathrm{~m}\end{array}$ & $\begin{array}{l}28.9^{\#}, \\
\mathrm{CH}_{2}\end{array}$ & $1.21-1.29, \mathrm{~m}$ & $\begin{array}{l}26.5^{*} \\
\mathrm{CH}_{2}\end{array}$ & $1.18-1.32, \mathrm{~m}$ \\
\hline $8^{\prime}$ & $\begin{array}{l}29.8, \\
\mathrm{CH}_{2}\end{array}$ & $\begin{array}{l}1.22-1.29 \\
\mathrm{~m}\end{array}$ & $\begin{array}{l}29.7^{*}, \\
\mathrm{CH}_{2}\end{array}$ & $\begin{array}{l}1.20-1.30 \\
\mathrm{~m}\end{array}$ & $\begin{array}{l}29.7^{*} \\
\mathrm{CH}_{2}\end{array}$ & $\begin{array}{l}1.22-1.29, \\
\mathrm{~m}\end{array}$ & $\begin{array}{l}29.0^{\#} \\
\mathrm{CH}_{2}\end{array}$ & $1.21-1.29, \mathrm{~m}$ & $\begin{array}{l}28.9^{*} \\
\mathrm{CH}_{2}\end{array}$ & $1.18-1.32, \mathrm{~m}$ \\
\hline $9^{\prime}$ & $\begin{array}{l}30.0, \\
\mathrm{CH}_{2}\end{array}$ & $\begin{array}{l}1.22-1.29, \\
\mathrm{~m}\end{array}$ & $\begin{array}{l}29.8, \\
\mathrm{CH}_{2}\end{array}$ & $\begin{array}{l}1.20-1.30, \\
\mathrm{~m}\end{array}$ & $\begin{array}{l}29.78^{*}, \\
\mathrm{CH}_{2}\end{array}$ & $\begin{array}{l}1.22-1.29 \\
\mathrm{~m}\end{array}$ & 29.3, $\mathrm{CH}_{2}$ & $1.21-1.29, \mathrm{~m}$ & $\begin{array}{l}29.0 \text {, } \\
\mathrm{CH}_{2}\end{array}$ & $1.18-1.32, \mathrm{~m}$ \\
\hline $10^{\prime}$ & $\begin{array}{l}27.5, \\
\mathrm{CH}_{2}\end{array}$ & $\begin{array}{l}1.22-1.29, \\
\mathrm{~m}\end{array}$ & $\begin{array}{l}30.1, \\
\mathrm{CH}_{2}\end{array}$ & $\begin{array}{l}1.20-1.30 \\
\mathrm{~m}\end{array}$ & $\begin{array}{l}29.81^{*}, \\
\mathrm{CH}_{2}\end{array}$ & $\begin{array}{l}1.22-1.29, \\
\mathrm{~m}\end{array}$ & $26.8, \mathrm{CH}_{2}$ & $1.24, \mathrm{~m}$ & $\begin{array}{l}29.4 \\
\mathrm{CH}_{2}\end{array}$ & $1.18-1.32, \mathrm{~m}$ \\
\hline $11^{\prime}$ & $\begin{array}{l}39.2 \\
\mathrm{CH}_{2}\end{array}$ & $1.13, \mathrm{~m}$ & $\begin{array}{l}36.8, \\
\mathrm{CH}_{2}\end{array}$ & $\begin{array}{l}1.07, \mathrm{~m} \\
1.28, \mathrm{~m}\end{array}$ & $30.1, \mathrm{CH}_{2}$ & $\begin{array}{l}1.22-1.29, \\
\mathrm{~m}\end{array}$ & $38.5, \mathrm{CH}_{2}$ & $1.13, \mathrm{~m}$ & $\begin{array}{l}36.0 \\
\mathrm{CH}_{2}\end{array}$ & $\begin{array}{l}1.06, \mathrm{~m} \\
1.25, \mathrm{~m}\end{array}$ \\
\hline $12^{\prime}$ & $\begin{array}{l}28.1, \\
\mathrm{CH}_{2}\end{array}$ & $1.50, \mathrm{~m}$ & $\begin{array}{l}34.5, \\
\mathrm{CH}\end{array}$ & $1.28, \mathrm{~m}$ & 27.6, $\mathrm{CH}_{2}$ & $\begin{array}{l}1.22-1.29, \\
\mathrm{~m}\end{array}$ & $27.4, \mathrm{CH}_{2}$ & $1.49, \mathrm{~m}$ & $\begin{array}{l}33.7, \\
\mathrm{CH}\end{array}$ & $1.28, \mathrm{~m}$ \\
\hline $13^{\prime}$ & $\begin{array}{l}22.8, \\
\mathrm{CH}_{3}\end{array}$ & $0.85, \mathrm{~d}(6.7)$ & $\begin{array}{l}29.6 \text {, } \\
\mathrm{CH}_{2}\end{array}$ & $\begin{array}{l}1.11, \mathrm{~m} \\
1.25, \mathrm{~m}\end{array}$ & $39.2, \mathrm{CH}_{2}$ & $1.15, \mathrm{~m}$ & $22.5, \mathrm{CH}_{3}$ & $0.84, \mathrm{~d}(6.6)$ & $\begin{array}{l}28.9, \\
\mathrm{CH}_{2}\end{array}$ & $\begin{array}{l}1.10, \mathrm{~m} \\
1.24, \mathrm{~m}\end{array}$ \\
\hline
\end{tabular}




\begin{tabular}{|c|c|c|c|c|c|c|c|c|c|c|}
\hline $14^{\prime}$ & $\begin{array}{l}22.8, \\
\mathrm{CH}_{3}\end{array}$ & $0.85, \mathrm{~d}(6.7)$ & $\begin{array}{l}11.5, \\
\mathrm{CH}_{3}\end{array}$ & $0.85, \mathrm{t}(7.2)$ & $28.1, \mathrm{CH}$ & $1.51, \mathrm{~m}$ & $22.5, \mathrm{CH}_{3}$ & $0.84, \mathrm{~d}(6.6)$ & $\begin{array}{l}11.2 \\
\mathrm{CH}_{3}\end{array}$ & $0.82, \mathrm{t}(7.2)$ \\
\hline $15^{\prime}$ & - & - & $\begin{array}{l}19.5 \\
\mathrm{CH}_{3}\end{array}$ & $0.83, \mathrm{~d}(6.4)$ & $22.8, \mathrm{CH}_{3}$ & $0.86, \mathrm{~d}(6.6)$ & - & - & $\begin{array}{l}19.1 \\
\mathrm{CH}_{3}\end{array}$ & $0.81, \mathrm{~d}(6.5)$ \\
\hline $16^{\prime}$ & - & - & - & - & $22.8, \mathrm{CH}_{3}$ & $0.86, \mathrm{~d}(6.6)$ & - & - & - & - \\
\hline
\end{tabular}


<smiles>CO[N+](C)=NCO[C@H]1O[C@H](COC2OC[C@@H](O)[C@H](O)[C@H]2O)[C@@H](O)[C@H](O)[C@@H]1O</smiles>

macrozamin

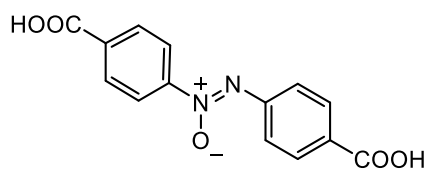

4,4'-azoxydibenzoic acid<smiles>CN=[N+]([O-])CC[C@H](N)C(=O)O</smiles>

azoxibacillin<smiles>CCCCCC/C=C\[N+]([O-])=N[C@@H](COC)[C@H](C)O</smiles>

elaiomycin

Figure 1. Structures of selected naturally occurring azoxides. Macrozamin from cycad plant; azoxibacillin produced by Bacillus cereus; 4,4'-azoxydibenzoic acid from entomopathogenic zygomycete Entomophthora virulenta; and elaiomycin produced by Streptomyces hepaticus.<smiles>COC(=O)[C@H](C)N=[N+]([O-])C=CCCCCCCCCC(C)C</smiles><smiles>CCC([18F])CCCCCCCCCC=C[N+]([O-])=N[C@@H](C)C(=O)OC</smiles>

2

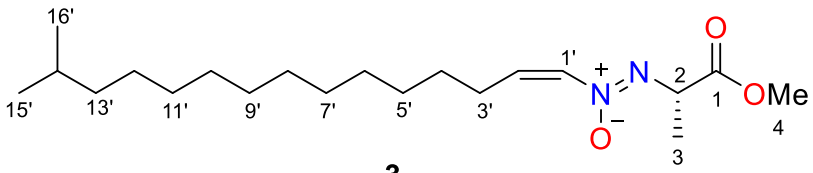

3<smiles>COC(=O)[C@H](C)N=[N+]([O-])C=CCCCCCCCCCC(C)C</smiles>

4<smiles>CCC(C)CCCCCCCCC/C=C/[N+]([O-])=N[C@@H](C)C(=O)OC</smiles>

5<smiles>COC(=O)[C@H](C)N=[N+]([O-])C=CCCCCCCCCCCCC(C)C</smiles>

6

Figure 2. Structures of compounds $\mathbf{1}-\mathbf{6}$.
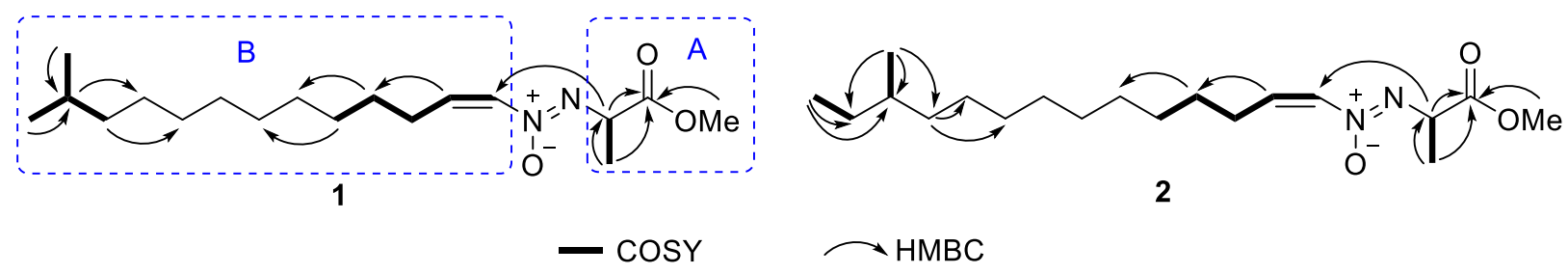

Figure 3. Selected COSY and HMBC correlations for compounds $\mathbf{1}$ and $\mathbf{2}$. 


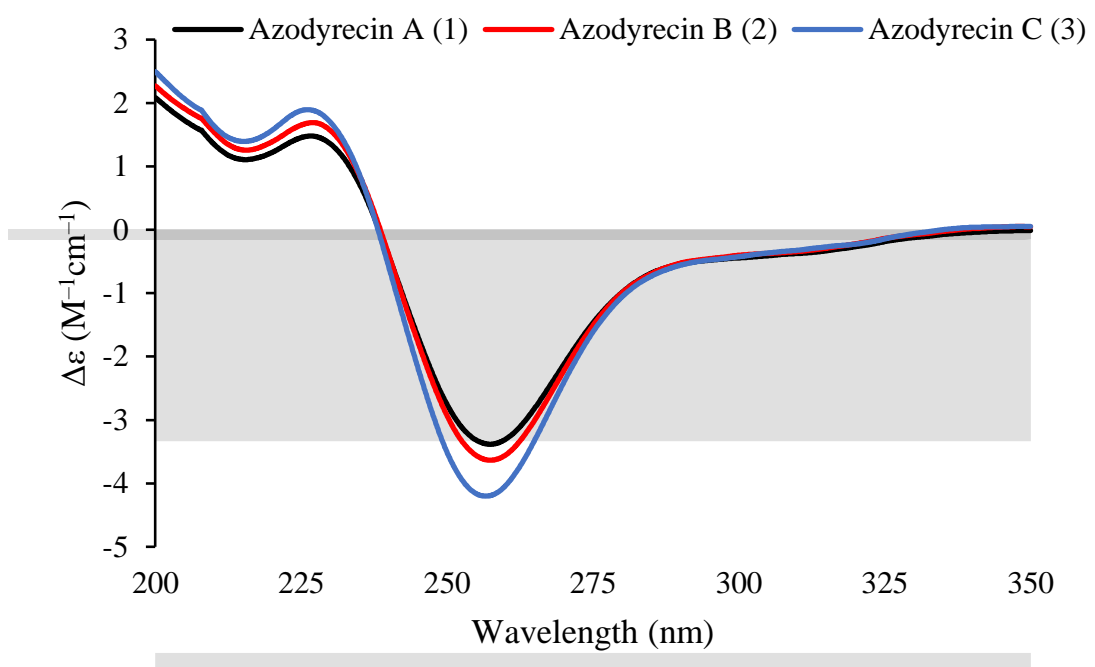

Figure 4. ECD curves of 1-3.

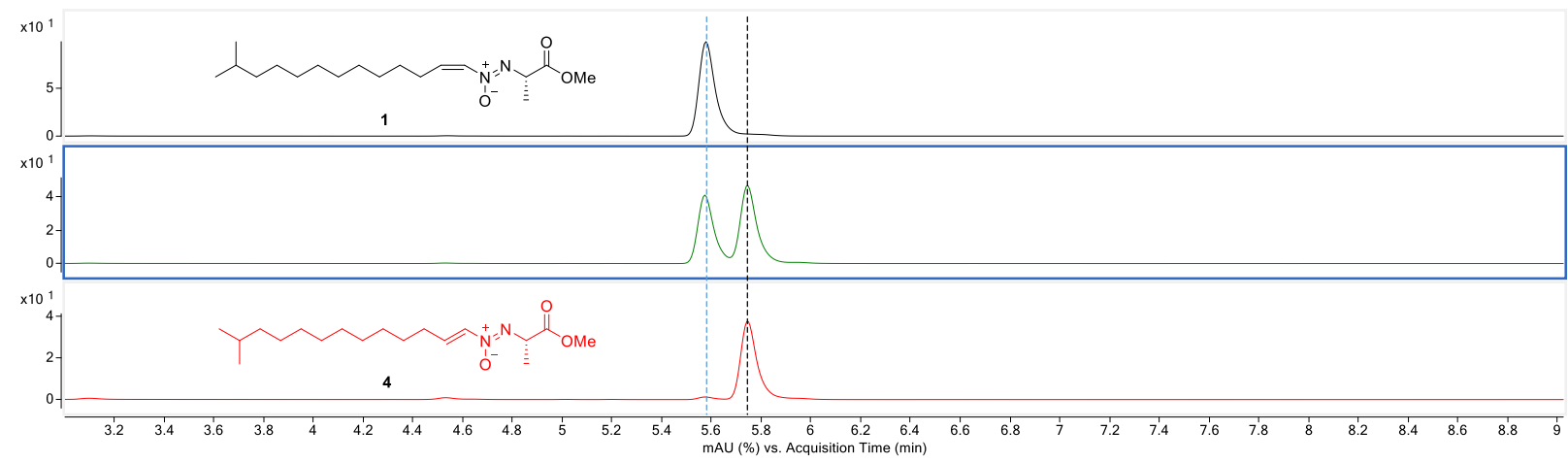

Figure 5. HPLC-UV ( $280 \mathrm{~nm}$ ) chromatograms showing the conversion of compound $\mathbf{1}$ (top panel) to compound 4 (bottom panel). Middle panel shows the mixture of compounds 1 and 4. 


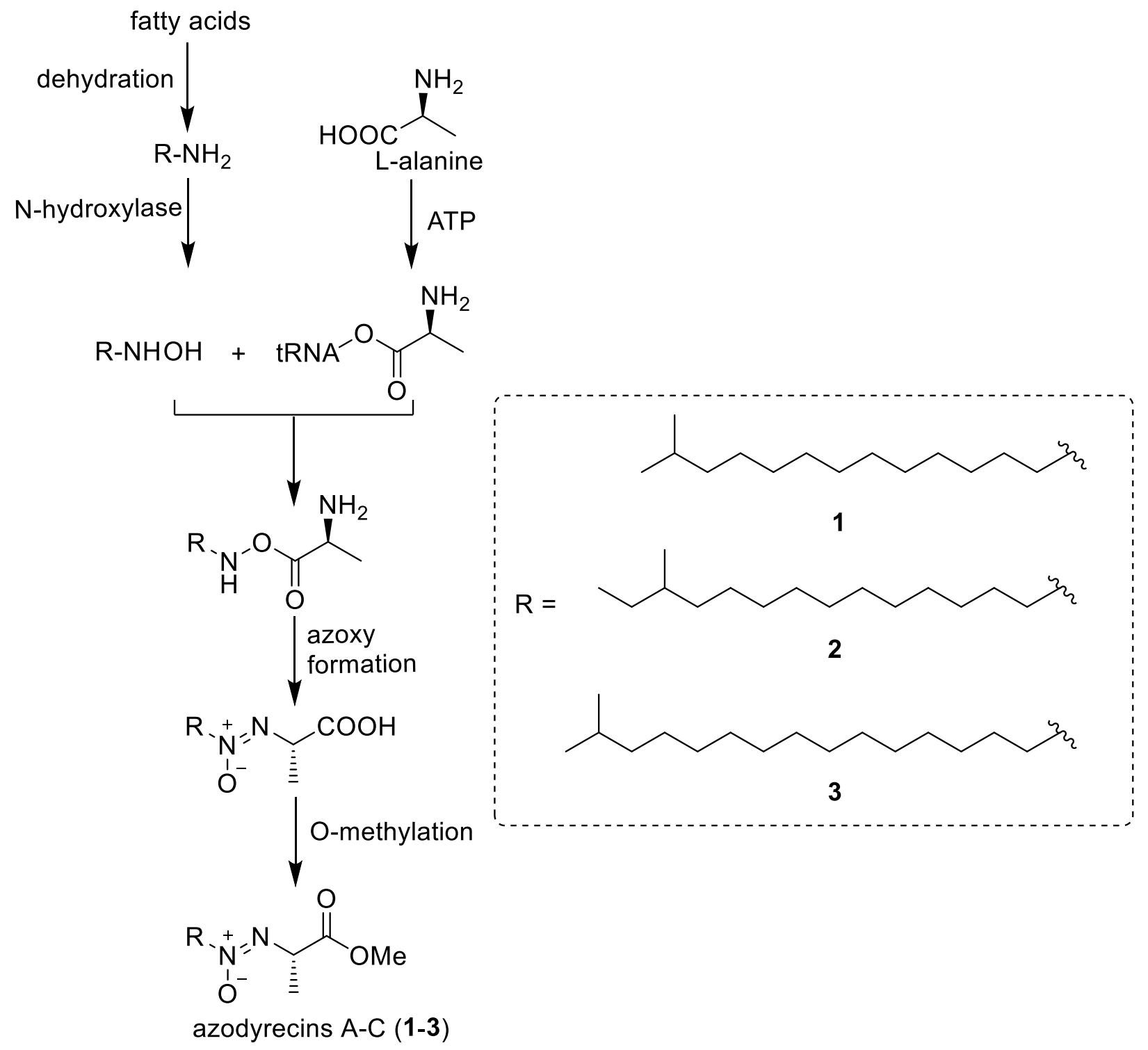

Figure 6. Plausible biosynthetic pathway for azodyrecins A-C (1-3). 
Table of Contents/Abstract Graphics

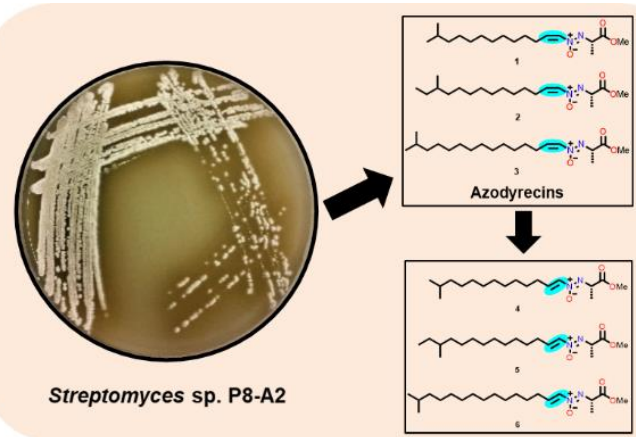

